University of Nebraska - Lincoln

DigitalCommons@University of Nebraska - Lincoln

Faculty Publications from the Harold W. Manter Laboratory of Parasitology

6-1975

\title{
Platyhelminths of Nebraska Turtles with Descriptions of Two New Species of Spirorchiids (Trematoda: Spirorchiidae)
}

Daniel R. Brooks

University of Toronto,dnlbrooks@gmail.com

Monte A. Mayes

University of Nebraska - Lincoln

Follow this and additional works at: https://digitalcommons.unl.edu/parasitologyfacpubs

Part of the Parasitology Commons

Brooks, Daniel R. and Mayes, Monte A., "Platyhelminths of Nebraska Turtles with Descriptions of Two New Species of Spirorchiids (Trematoda: Spirorchiidae)" (1975). Faculty Publications from the Harold W. Manter Laboratory of Parasitology. 241.

https://digitalcommons.unl.edu/parasitologyfacpubs/241

This Article is brought to you for free and open access by the Parasitology, Harold W. Manter Laboratory of at DigitalCommons@University of Nebraska - Lincoln. It has been accepted for inclusion in Faculty Publications from the Harold W. Manter Laboratory of Parasitology by an authorized administrator of DigitalCommons@University of Nebraska - Lincoln. 


\title{
PLATYHELMINTHS OF NEBRASKA TURTLES WITH DESCRIPTIONS OF TWO NEW SPECIES OF SPIRORCHIIDS (TREMATODA: SPIRORCHIIDAE)
}

\author{
Daniel R. Brooks* and Monte A. Mayes \\ School of Life Sciences, University of Nebraska-Lincoln, and \\ Harold W. Manter Laboratory, Division of Parasitology, \\ University of Nebraska State Museum, Lincoln, Nebraska 68508
}

\begin{abstract}
Twenty-one species of platyhelminth parasites are reported from 8 species of turtles collected in Nebraska. Two species of spirorchiids are reported as new. Vasotrema brevitestis $\mathrm{sp} . \mathrm{n}$. from Trionyx muticus and T. spiniferus differs from $V$. amydae Stunkard, 1926, in possessing a relatively shorter, more compact testis, postcecal length equal to one-fifth the body length, a cirrus sac which does not extend to the opposite cecum, and vitellaria composed of discrete follicles more restricted in distribution. Hapalorhynchus foliorchis sp. n. from Chelydra serpentina differs from $H$. gracilis Stunkard, 1922 , in possessing a narrower oral sucker and larger acetabulum, a prominent esophageal constriction, smaller ovary and larger, irregular testes, postcecal space equal to one-sixth the body length, and ventrally oriented uterus. Five other species, Allassostomoides chelydrae, Diarmastorchis blandingi, Vasotrema amydae, V. attenuatum, and Ophiotaenia testudo, are reported for the first time since their description. Nineteen species are reported from Nebraska for the first time. New host records are Trionyx muticus for Vasotrema attenuatum and V. robustum and Graptemys pseudogeographica (Gray) for Allassostomoides chelydrae.
\end{abstract}

From June 1973 until October 1974, the authors collected 16 species of platyhelminths from 55 turtles representing seven species captured in Nebraska (Table I). The results were combined with unpublished data compiled by H. W. Manter for the period 1947-49, bringing the total to 21 species of worms from eight species of turtles. Two species of spirorchiid trematodes are described as new. Spirorchiids were killed with hot water and immediately transferred to AFA. Other worms were flattened with slight coverslip pressure and fixed with AFA. All were stored in $70 \%$ ethanol; stained with Mayer's carmalum, Mayer's hematoxylin, or Delafield's hematoxylin; and mounted in Canada balsam. Figures were drawn with the aid of a camera lucida. All measurements are in microns. Dimensions of organs are stated as length by width.

\section{Family Spirorchiidae Stunkard, 1921 Vasotrema brevitestis sp. $n$.}

(Fig. 1)

Description (measurements based on 20 of 34 specimens): Body spindle-shaped, weakly muscled; length 1,300 ( 1,246 to 1,428$)$, width 115 ( 108 to 124). Small spines present on anterior end of body, most conspicuous on oral sucker. Oral sucker sub-

Received for publication 25 November 1974.

* Present address: Gulf Coast Research Laboratory, P.O. Box A. G., Ocean Springs, Mississippi 39564 terminal, oval, diameter 50 ( 40 to 56 ); acetabulum at anterior end of second third of body, round, diameter 50 (38 to 52). Esophagus 190 long, with ring of prominent diverticula at beginning of posterior third of esophagus. Intestinal bifurcation preacetabular, ceca relatively long; postcecal space one-fifth body length. Testis relatively short, compact, exhibiting some degree of torsion; intercecal at mid-hindbody; 260 (231 to 310 ) by 90 (70 to 100); ratio of testis length to body length 1:5. Vas deferens straight, passing lateral or dorsal to ovary. Seminal vesicle external, saccular, connected to cirrus sac by short duct. Cirrus sac short, diagonal, not extending to opposite cecum, 72 ( 66 to 78 ) by 12 ( 11 to 12 ); containing pars prostatica and straight cirrus. Genital pore ventral, posterosinistral to acetabulum. Ovary pretesticular, round to slightly irregular, 40 by 38 ( 34 to 40 ). Seminal receptacle postovarian, large, filling intercecal space between ovary and testis. Laurer's canal short; Mehlis' gland composed of very small cells. Uterus saccular, preovarian, sinistral, opening at genital pore. Vitelline follicles discrete, 20 to 40 in number, 12 in diameter; most numerous in region of seminal receptacle, extending dorsally from testicular to acetabular region. Single mature egg 20 by 16; single immature egg 36 by 30 . Excretory pore terminal, vesicle convoluted in postcecal region.

Type host: Trionxy muticus (LeSueur), smooth soft-shelled turtle.

Type locality: Missouri River, 1.5 miles south of Blair, Nebraska.

Another host and locality: T. spiniferus (LeSueur), spiny soft-shelled turtle, Atkinson State Recreation Area, 0.5 mile west of Atkinson, Nebraska.

Type specimens: Holotype and two paratypes 
TABLe I. Parasite-host list of playthelminths in turtles from Nebraska.

\begin{tabular}{|c|c|c|}
\hline Parasite & Host & $\begin{array}{l}\text { No. Inf./No. } \\
\text { examined }\end{array}$ \\
\hline \multirow{3}{*}{$\begin{array}{l}\text { Digenea; Allassostomoides chelydrae } \\
\quad \text { (MacCallum, 1919) Yamaguti, } 1958\end{array}$} & Chelydra serpentina & $1 / 18$ \\
\hline & Chrysemys picta* & $1 / 21$ \\
\hline & Graptemys pseudogeographica* & $1 / 4$ \\
\hline \multirow{2}{*}{$\begin{array}{l}\text { Allassostomoides parvus } \\
\quad \text { (Stunkard, 1917) Stunkard, } 1925\end{array}$} & Chelydra serpentina & $1 / 18$ \\
\hline & Chrysemys picta & $4 / 21$ \\
\hline \multirow{2}{*}{$\begin{array}{l}\text { Auridistomum chelydrae } \\
\qquad \text { (Stafford, 1900) Stafford, } 1905\end{array}$} & Chelydra serpentina & $5 / 18$ \\
\hline & Chrysemys picta & $1 / 21$ \\
\hline Cephalogonimus vesicaudus $\dagger$ Nickerson, 1912 & Trionyx spiniferus & - \\
\hline \multirow{4}{*}{$\begin{array}{l}\text { Diarmastorchis blandingi (MacCallum, 1926) Ejsmont, } 1927 \\
\text { Heronimus mollis (Leidy, 1856) Stunkard, } 1964\end{array}$} & Emydoidea blandingi & $2 / 2$ \\
\hline & Chelydra serpentina & $3 / 18$ \\
\hline & Chrysemys picta & $2 / 21$ \\
\hline & Emydoidea blandingi & $1 / 2$ \\
\hline \multirow{2}{*}{$\begin{array}{l}\text { Hapalorhynchus foliorchis sp. n. } \\
\text { Protenes angustus } \dagger \text { (Stafford, 1900) Ward, } 1918\end{array}$} & Chelydra serpentina & $1 / 18$ \\
\hline & Chrysemys picta & - \\
\hline Spirorchis hematobium Stunkard, 1922 & Chelydra serpentina & $1 / 18$ \\
\hline \multirow{2}{*}{$\begin{array}{l}\text { Telorchis attenuatus Goldberger, } 1911 \\
\text { Telorchis corti Stunkard, } 1915\end{array}$} & Chrysemys picta & $2 / 21$ \\
\hline & Chelydra serpentina & $2 / 18$ \\
\hline & Graptemys pseudogeographica & $2 / 4$ \\
\hline & Trionyx spiniferus & $1 / 6$ \\
\hline Telorchis medius Stunkard, 1915 & Emydoidea blandingi & $1 / 2$ \\
\hline \multirow{3}{*}{$\begin{array}{l}\text { Vasotrema amydae Stunkard, } 1926 \\
\text { Vasotrema attenuatum Stunkard, } 1928\end{array}$} & Trionyx spiniferus & $1 / 6$ \\
\hline & Trionyx muticus & $1 / 1$ \\
\hline & Trionyx spiniferus & $1 / 6$ \\
\hline \multirow[t]{2}{*}{ Vasotrema brevitestis sp. $\mathrm{n}$. } & Trionyx muticus* & $1 / 1$ \\
\hline & Trionyx spiniferus & $1 / 6$ \\
\hline \multirow[t]{2}{*}{ Vasotrema robustum Stunkard, 1928} & Trionyx muticus* & $1 / 1$ \\
\hline & Trionyx spiniferus & $4 / 6$ \\
\hline Monogenea; Neopolystoma orbiculare $\dagger$ (Stunkard, 1916) & Chrysemys picta & - \\
\hline Polystomoidella oblonga $\dagger$ (Wright, 1879) Price, 1939 & Chelydra serpentina & - \\
\hline Polystomoidella whartoni† Price, 1939 & Kinosternon flavescens & - \\
\hline Polystomoides coronatum (Leidy, 1888) Ozaki, 1935 & Chrysemys picta & $1 / 21$ \\
\hline Cestoidea; Ophiotaenia testudo Magath, 1924 & Trionyx spiniferus & $3 / 6$ \\
\hline
\end{tabular}

* New host record.

† Recovered in 1947-49 and not in present study.

USNM Helm. Coll. Nos. 73817-73819. Paratype series H. W. Manter Laboratory Nos. 20076, 20077. Other paratypes in collections of authors.

\section{Discussion}

The genus Vasotrema Stunkard, 1926, was erected for V. amydae in the circulatory system of Amyda (=Trionyx) spinifera from Illinois and A. ferox (Schneider) from Florida. Stunkard (1928) subsequently described V. attenuatum and $V$. robustum from the same hosts and localities. Byrd (1939) reported V. robustum and a new species $V$. longitestis in T. spiniferus from Reelfoot Lake, Tennessee. Wall (1951) described the life cycle of $V$. robustum in T. spiniferus and T. ferox.

Vasotrema brevitestis most closely resembles $V$. amydae from which it differs in possessing a relatively shorter, more compact testis, and postcecal space equal to one-fifth the body length as opposed to one-sixth; a cirrus sac which does not extend to the opposite cecum; and vitellaria composed of relatively few, large, discrete follicles not extending posterior to the testis as opposed to the abundant, dispersed follicles extending to the cecal tips in $V$. amydae. In recognizing a fifth species of the genus, the authors have prepared the following key:

\section{Key to species of Vasotrema Stunkard, 1926} (syn. Vasatrema Stunkard, 1926)

1 a) Vitelline follicles small _..._................ 2

b) Vitelline follicles large

2 a) Testis elongate, unspiraled or slightly torqued _.._-_._-attenuatum

b) Testis a loose spiral _..._._._._._._. amydae

c) Testis a tight spiral of many coils longitestis

3 a) Genital pore some distance from acetabulum, acetabulum much larger than oral sucker _.__ robustum

b) Genital pore immediately postacetabular, acetabulum and oral sucker subequal

brevitestis 


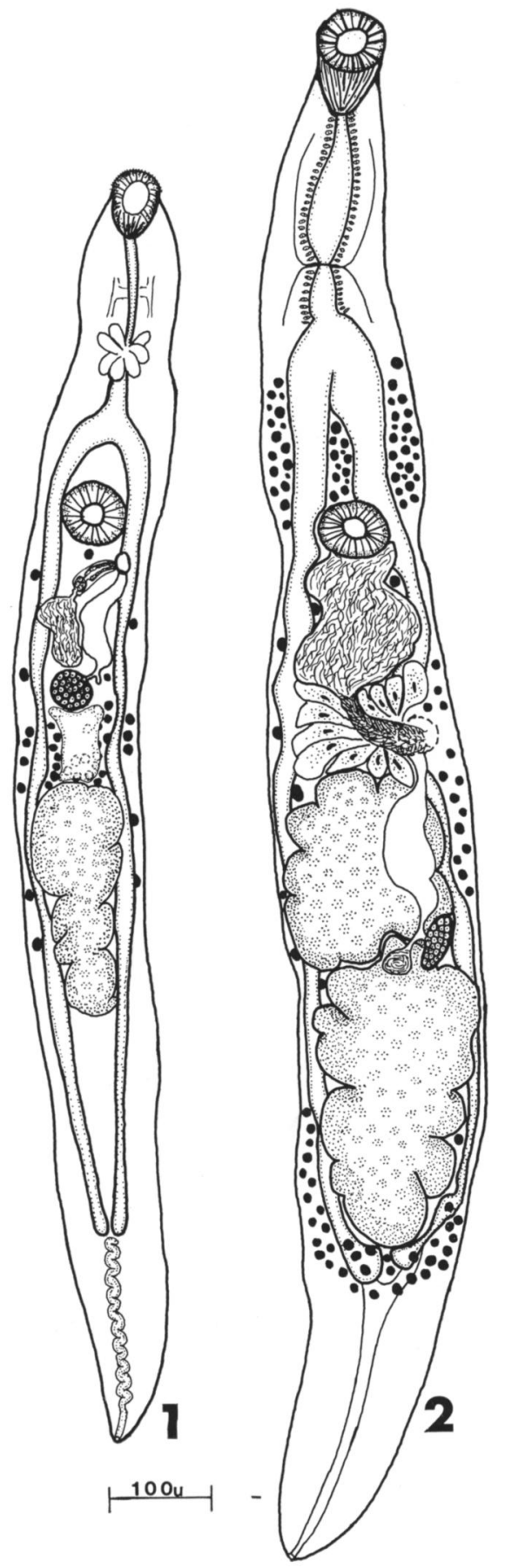

Figures 1-2. New trematodes from Nebraska
turtles, ventral view. 1. Vasotrema brevitestis sp. $\mathrm{n}$.

Figures 1-2. New trematodes from Nebraska
turtles, ventral view. 1. Vasotrema brevitestis $\mathrm{sp.} \mathrm{n}$. 2. Hapalorhynchus foliorchis sp. $\mathrm{n}$.

\section{Hapalorhynchus foliorchis sp. n.}

(Fig. 2)

Description (measurements based on 24 of 34 specimens): Body smooth, tapering at both ends, widest in posterior half, with a constriction at the level of acetabulum; length 1,560 (1,427 to 1,681 ), width 200 ( 164 to 238 ) near mid-hindbody. Oral sucker subterminal, protrusible, 60 wide ( 50 to 71); acetabulum one-third body length from anterior end, 71 long ( 67 to 81 ) by 77 wide ( 71 to 85 ). Esophagus 212 long (182 to 242 ), dilated and surrounded by gland cells, constricted in posterior third at level of cerebral commissure. Intestinal bifurcation preacetabular, ceca long; postcecal space equal to one-fifth body length. Testes contiguous, irregular; anterior testis 164 (131 to 202 ) by 145 ( 111 to 176 ); posterior testis 233 ( 182 to 303 ) by 146 ( 117 to 172 ). Seminal vesicle large, abutting posterior margin of acetabulum; with a short, straight duct leading to weakly muscled ductus ejaculatorius, surrounded by large, prominent prostatic gland cells. Genital pore dorsal, 150 to 220 posterior to acetabulum, lateral to sinistral cecum. Cecum indented at level of genital pore. Ovary intertesticular, oval to round, 56 ( 44 to 67 ) by 33 ( 22 to 55 ), sinistral, abutting left cecum. Seminal receptacle small, posteromedian to ovary. Laurer's canal short, straight; Mehlis' gland cells small. Uterus sinistral, saccular, ventral to anterior testis, opening at genital pore, containing no eggs. Vitelline follicles abundant, extending dorsally from intestinal bifurcation to cecal tips. Excretory pore terminal, bladder Y-shaped, bifurcating at level of cecal tips.

Type host: Chelydra serpentina (Linnaeus), snapping turtle.

Type locality: Missouri River, 1.5 miles south of Brownville, Nebraska.

Type specimens: Holotype and two paratypes USNM Helm. Coll. Nos. 73820, 73821. Paratype series H. W. Manter Coll. No. 20078. Other paratypes in collections of authors.

\section{Discussion}

The genus Hapalorhynchus Stunkard, 1922, was erected for $H$. gracilis in the circulatory system of $C$. serpentina from Indiana. Byrd (1939) reported $H$. gracilis and described three additional species, $H$. evaginatus in Trionyx spiniferus, $H$. reelfooti in Sternotherus odoratus (Latreille), and H. stunkardi in Kinosternon (= Sternotherus) carinatum (Gray) from Reelfoot Lake in Tennessee. A report by Guilford (1959) of $H$. gracilis in $C$. serpentina from the Menominee River in Michigan is the only other report found by the authors concerning the species of this genus.

Hapalorhynchus foliorchis most closely resembles $H$. gracilis, but differs in possessing a 
narrower oral sucker and larger acetabulum, and a prominent esophageal constriction. The ovary is extremely small compared to that of $H$. gracilis; the testes are much larger, and highly irregular in outline as opposed to the smooth testes of $H$. gracilis. The postcecal space of $H$. foliorchis is equal to one-sixth the length of the body while that of $H$. gracilis is one-fifth. Finally, the uterus of $H$. foliorchis passes ventrally to the anterior testis while in $H$. gracilis the uterus passes dorsally.

A combined total of 21 species of platyhelminths is reported (Table I). Except for Protenes angustus, which was reported by Barker and Covey (1911) and Heronimus chelydrae, which was reported by Barker and Parsons (1914), all species listed in this paper are reported for the first time from Nebraska. Five species, Allassostomoides chelydrae, Diarmastorchis blandingi, Vasotrema amydae, V. attenuatum, and Ophiotaenia testudo, are reported for the first time since their original description. Trionyx muticus is a new host for Vasotrema attenuatum and $V$. robustum; Graptemys pseudogeographica is a new host for Allassostomoides chelydrae.

A comparison of sex and age of hosts examined with numbers of species of platyhelminths recovered indicates that the older the turtle, the more likely it is to be infected with platyhelminths and the more species of platyhelminths it is likely to harbor. This is especially true in the case of Ophiotaenia testudo. Magath (1924) reported that he found this cestode only in soft-shelled turtles having a carapace 8 or more inches in length, and that all such turtles were infected with the worm. All infected turtles reported by Magath must have been mature females, since male softshelled turtles do not attain such a length. In this study, all three females 8 inches or longer in carapace length harbored O. testudo; no others of either sex were infected. As mentioned by Magath, it is possible that the inter- mediate host is of such a size that only the large turtles would be able to feed upon it and become infected.

\section{ACKNOWLEDGMENTS}

The authors wish to express their appreciation to Dr. Charles Wallace, Research Division Nebraska Game and Parks Commission, for his aid in obtaining turtles; to Dr. John D. Lynch, School of Life Sciences, University of Nebraska-Lincoln, for his help in identifying hosts; to Dr. Horace W. Stunkard, Research Associate, American Museum of Natural History, for arranging the loan of pertinent type material; and Mrs. Mary Hanson Pritchard, School of Life Sciences, University of Nebraska-Lincoln, under whose direction these studies were undertaken.

\section{LITERATURE CITED}

Barker, F. D., and G. W. Covey. 1911. A new species of trematode from the painted terrapin, Chrysemys marginata Agassiz. Univ. Studies, Univ. Nebr. 11 (3): 193-218.

$\longrightarrow$, and S. Parsons. 1914. A new species of monostome from the painted terrapin, Chrysemys marginata. Zool. Anz. 45 (5): 193194.

Byrd, E. E. 1939. Studies on the blood flukes of the family Spirorchiidae. Part II. Revision of the family and description of new species. J. Tenn. Acad. Sci. 14 (1) : 116-161.

Guilford, H. G. 1959. Some helminth parasites found in turtles from northeastern Wisconsin. Tr. Wis. Acad. Sci., Arts, and Lett. 48: 121124.

Magath, T. B. 1924. Ophiotaenia testudo, a new species from Amyda spinifera. J. Parasit. 11 ( 1 ): 44-49.

Stunkard, H. W. 1928. Observations nouvelles sur les trématodes sanguinicoles du genre Vasotrema (Spirorchidae) avec descriptions des deux espèces nouvelles. Ann. Parasitol. Hum. et Comp. 6 (3) : 303-320.

WALL, L. D. 1951. The life history of Vasotrema robustum (Stunkard, 1928) Trematoda : Spirorchiidae. Tr. Amer. Micr. Soc. 70 (2): 173-184. 